\title{
LEGAL PROTECTION OF THE RIGHTS OF OLDER PERSONS AGAINST AGEISM
}

\author{
M. PILAR MUNUERA GÓMEZ ${ }^{1}$
}

\author{
M. ELENA BLANCO LARRIEUX ${ }^{2}$
}

\begin{abstract}
Human beings go through stages of vulnerability during their evolution and development. Old age is one of these. The rights of older persons are acknowledged to a certain degree but have not yet been developed into an integral system like the rights of other groups, for instance the handicapped, have. Spanish legislation contemplates the rights of older persons to guarantee their social protection. The objective of this paper is to reveal the need of a single unified law to guarantee these rights. For this purpose, existing Spanish legislation has been reviewed, finding the underlying principles of this protection is based in the 1948 Universal Declaration of Human Rights. In current times older persons have ceased to be respected by their age and social position and sometimes find themselves socially excluded or legally unprotected. This circumstance claims a solution to avoid illtreatment. It calls for an institutional solution: the drafting of a charter of rights of the older person which would avoid behaviours that disregard this group, harming their dignity as individuals. It is difficult for older persons to gain respect for their participation as citizens because their social conditions are not equal to that of the rest of citizens who are allowed to make their rights effective and thus ensure their respect.
\end{abstract}

Keywords: Ageism; rights; individuals; older persons; needs; protection; citizens.

\section{INTRODUCTION}

Discrimination based on age is reflected in society's attitude in all contexts of daily life. This situation has generated social and legal vulnerability and therefore calls for the response of institutions to address the recognition of older persons rights. Currently they are seen as a burden; this view makes older persons feel less valued and as a result they are more prone to depression and social isolation. At present, the separation between subject and object in a capitalist system leads to the invisibility of those agents considered non productive economically, as is the case of older persons (Riesco, 2016:100).

The recognition of the rights of older persons is coherent with existing protection of the elderly and can be situated within the scope of international human rights. This recognition implies the respect of the needs each person has to fulfill its

\footnotetext{
${ }^{1}$ Professor, Faculty of Social Work, Universidad Complutense de Madrid, Spain (pmunuera@ucm.es).

2 Doctor in Law and Social Sciences, University of the Republic, Uruguay

(mariaelenablancolarrieux@gmail.com).
} 
development (Bondía, 2013). Governments must satisfy these rights. The right to the protection of old age is based in the European constitutions of the early $19^{\text {th }}$ century. The Weimar Constitution, of 11 November 1919, stands out as a reference to other later constitutions both in Europe and in America, for having developed a strong social philosophy proposing the recognition of social rights which the state had to attend to, including health protection throughout the person's life and particularly at times of major weakness (López, 2010:234). Article 161 states:

"In order to attend to the conservation of health and capacity to work, to the protection of motherhood and of economic consequences of old age, sickness and life's downturns the Empire will create an ample system of insurance with the participation of the interested parties” (art. 161).

In this sense it is noteworthy that in 1919 social protection of health by the state was focussed on the weakest social groups, amongst which were the elderly and the workers, based on the social democratic idea that the integral development of the human being recquires that an organized society and the state act positively to create the conditions necessary to achieve these rights (Abreu \& Abreu, 2009). Similar ideas can be found in the preamble of the 1946 French Constitution. In its eleventh point, this document guarantees all but particularly children, mothers and retired workers, health protection and the right to rest and recreation. Article 32 of the Italian Constitution of 1947 states:

"The Republic protects health as a basic right of the person and as a basic interest of the community and assures free health care for the needy.

No one will be forced to undergo medical treatment unless the Law demands it. The Law will in no case violate the limits of the respect of the person" (art. 32)

Later on, the recognition of civil and political rights increases until it reaches the most significant and recent documents as is the case of the 1948 Universal Declaration of Human Rights (Paris, December 10th, 1948) which states in article 25.1: "Everyone has the right to a standard of living adequate for the health and well being of himself and of his family, including food, clothing, housing and medical care and necessary social services, and the right to security in the event of unemployment, sickness, disability, widowhood, old age or other lack of livelihood in circumstances beyond his control”. Some of the rights that are guaranteed in this Declaration have not been put into practice. Their inclusion has not meant in all cases, their fulfillment (Lema, 2012: 35-36).

Human Rights are defined as a legal and axiological system which represents the fundamental values of the human being, from the point of view of the western civilization (Villasmil \& Chirinos, 2016: 197). After an extensive working life and ensuring the welfare of their families, older persons deserve to be treated with utmost respect and consideration by the rest of the population. As we age, every person has to be respected, and consideration has to be made of the multiple contributions: by way of 
direct participation in the workforce (either formal or informal), payment of taxes, consumption of goods, transfers of money, teaching to younger generations as well as numerous other less tangible contributions that citizens make within their families and communities (OMS, 2015). The concept of older pesons as subjects of law is part of a wider context of theoretical and political analysis refereed to the acknowledgement of rights to certain disadvantaged groups (Huenchaun \& Morlachetti, 2006: 50). Social protection of the older persons may be one of the criteria used to indicate the degree of social welfare. The improvement of recognition of older persons's rights may be achieved by making good use of available information and communications technologies (ICT) which allow different methods of decision making and participation $^{3}$. It is necessary to face the deep causes of inequality, and guarantee that all generations have equal access to health and social welfare as well as to continuous education and all opportunities which result in contributions to sustainable growth.

In the local context we tend to divide reality in order to study its essence. In some cases this method is not helpful, because the result is that the investigator loses sight of the basic premise, which is the integral respect of the inherent rights of human beings. The absence of legislation regarding the recognition of the rights of older persons favours lack of protection of such rights.

In the international sphere several initiatives have been presented resulting in the United Nations declaration of rights of older persons.

- The first proposal for a declaration of rights of the older person was made in Argentina in 1948 but did not go forward,

- In 1991 there is another attempt by the International Federation of Old Age and the Dominican Republic presents its proposal, Declaration of rights and duties of the older person, which constituted the basis of the United Nations Principles in favour of older persons, adopted by the General Assembly in 1991.

- In 1999 during the International Year of the Older Persons, the American Association of Retired Persons proposed a Charter for a society for people of all ages before the United Natinos, but it wasn't adopted either.

- The Interamerican Convention for the protection of the rights of the older person constitutes a binding treaty which aims to protect and promote the rights of the older person. ${ }^{4}$

The 1948 Universal Declaration of Human Rights was the first legal document to protect human rights. Together with the International Covenant on Civil and Political Rights and the International Covenant on Economic, Social and Cultural Rights these three documents constitute the International Charter on Human Rights. Other

\footnotetext{
3 The Department of Employment and Social Policies of the Basque Government has created 'Gobernantza+65'; this process has the objective of an initiative of generating a debate about the model of representation older persons could take in social and political decision making taking into account their knowledge, needs and interests. Another example is the platform which defends older persons'rights:http://publications.age-platform.eu/index.php

${ }^{4}$ Information available at: http://www.ohchr.org/SP/Issues/Pages/ListOfIssues.aspx
} 
international treaties have increased international human rights legislation since 1948. Until now there have been several proposals regarding the protection of older persons such as the United Nations Principles for Older Persons, the International Plan of Action on Ageing, adopted by the World Assembly on Ageing and endorsed by the General Assembly in its resolution 37/51 of 3 December 1982, the declaration of Rights of Older Persons or the Charter on Rights of Older Persons drawn up by the European Federation for Older Persons (EURAG). There are other firm initiatives in the United Kingdom, Ireland or Belgium; for different reasons these documents either have not been finished or the joint proposal by the countries has not been presented.

At present, there are different proposals which recognize the rights of older persons, which have evolved in the last decades in scattered and fragmented fashion. This makes it difficult to consolidate the rights of older persons and limits the capacity of UN member states and of the international community as a whole to grant the special protection that older persons need in order to fully enjoy their fundamental human rights as other sectors of society do.

In the majority of existing legal instruments age is nos included as a possible cause of discrimination (UN, General Assembly, 2009:7). The protection of rights of older persons has been included due to the broad interpretation that has been made by the supervising organs (Huenchuan, 2013). In 1995 the Committee on Economic, Social and Cultural Rights (CESCR) approved its General Observation no. 6, regarding the economic, social and cultural rights of older persons. This Committee has increased the rights established in the Covenant through its general Observation no. 14, regarding the right to enjoy the highest attainable standard of health (article 12, year 2000); Observation no. 19, regarding the right to social security (article 9, year 2008) and Observation no. 20, regarding non discrimination in economic, social and cultural rights (article 2, 2009) (Huenchuan, 2013).

\section{AgEISM. Social DisCRimination BASED ON AGE}

Dr. Robert N. Butler in 1969, coined the term ageism and defined it as a prejudice and discrimination against members of a group, in this case against the elderly or older persons (Butler, 1969). Ageism has been identified as the third greatest form of discrimination in our society, after racism and sexism (Losada, 2018). Barranco states:

"According to the reflection stated above, vulnerability depends on a personal condition shared by the members of a group. The identification of a group as vulnerable based on this concept permits justifying a differentiated treatment which is directed, mainly, to the protection of the members, and adopts an almost exclusive perspective of standardization” (Barranco, 2015: 33).

Age is therefore a social construction by means of which we define what is "appropriate" for every age or every stage of the life of human beings. Social 
discrimination by age must be revised since chronological age does not determine the person's capacity or autonomy.

Being old or elderly has been related wtih physical incapacity, with loss of mental capacity, weakness, dependency, isolation, loss of social and economic status and a long list of etceteras which constitute stereotypes that do not necessarily apply nowadays to a vast number of people from 65 to 80 years of age. Results of the World Values Survey, analysed by the World Health Organization (WHO, 2016) collecting data from over 83,000 people from 57 countries, reflect that over $60 \%$ of respondents believe that older persons are not treated with the respect owed to them. This is reported as a generalized problem in high income countries where the degree of respect for this age group is even lower.

At present retirement age is set at 65, but that doesn't mean that people at that age find themselves in situations of dependency or rather the opposite, most people at that age still retain full capacity to make their decisions and to participate in society. Because of this, public policy must be directed towards the construction of egalitarian societies inclusive of people of all ages. It would reflect an evolution with respect to the present paradigm of intervention in the older people age group which considers age only as a demographic, financial and sanitary consequence of the ageing population.

The social situation of the elderly and the culture associated with it require that all agents get together in constructing and making the new paradigm a reality by acknowledging human rights of this group. One of the most extensive principles is equality, so one of the most widespread rights is non discrimination based on age. At a legal level this is accepted. However in daily life old age persons undergo situations of physical, family or social abuse through constant examples of inequality which reveal an ageist society. Old persons' human rights are in constant danger of being overlooked. The intention is to look at their reality from the perspective of "the right to hold rights".

Discrimination based on age derives from the historical and social perspective regarding the roles, identities and values commonly attributed to older persons which are learned in the process of socialization. Nowadays an asymmetrical relationship of domination and subordination has been forged where the older person loses the right to decide. The goal is that the older person regains power in its widest sense: the power to chose, the power to create, the power to know, the power to learn, the power to enjoy, be chosen etc.

The perspective where old age is considered a human rights matter contributes to create awareness that different capacities are a vital fact in human beings where older persons must be included in order to prevent that ageism, one of the worse forms of discrimination, becomes widespread without even being recognized or identified.

The recognition of older persons' Human Rights calls above all, for a change of paradigm to overcome the association between old age and loss, to place older persons as subjects of rights and not only as benefitiaries, which implies empowerment of this 
group and a more integrated society. The fundamental principle is the recognition of the older persons' full citizenship, meaning not only the recognition of their rights but also of their dignity, autonomy, decision making, privacy and the improvement of communication based on care aiming at a more humane assistance (Bárcena et al, 2009)

\section{RIGHTS OF OLDER PERSONS THROUGHOUT HISTORY}

Due to their condition as human beings, older persons are potrected by binding human rights legislation. Older persons' homes must contemplate said legislation. Being included in the category of dependent population their rights are therefore recognized by the 1948 Universal Declaration of Human Rights which states that: "All are equal before the law and are entitled without any discrimination to equal protection of the law. All are entitled to equal protection against any discrimination in violation of this Declaration and against any incitement to such discrimination” (article 7).

The rights of older persons may be recognized in other international instruments such as the International Covenant on Civil and Political Rights, the International Covenant on Economic, Social and Cultural Rights, the American Declaration of the Rights and Duties of Man, the American Convention on Human Rights as well as its additional Protocol regarding economic, social and cultural rights (from here on San Salvador Protocol), the Asia-Pacific Forum of National Human Rights Institutions ${ }^{5}$, etc.

The Vienna International Plan of Action on Ageing (1982) states the guidelines to be followed by EU member states with respect to policies regarding prevention and health care of the older person. General Comment $n^{\circ} 6$ was adopted by the Comittee on Economic, Social and Cultural Rights and is considered one of the main standards regarding human rights and liberties for older persons ${ }^{6}$. In the Madrid International Plan of Action on Ageing (2002) the first definitions of the rights of older persons are set up and an initial plan for their safeguard is designed. This document contains a declaration of rights regarding non discrimination based on age, also regarding the dignity of older persons and the ability of the elderly to contibute in society. In this declaration there is a plea for a change in attitudes, policies and practices so that older persons can achieve their maximum development and potential ${ }^{7}$.

\footnotetext{
${ }^{5}$ This organization has called attention as to vulnerability of older persons and the ill treatment at institutional level due to its "systemic rather than individual nature" claiming a joint response on the part of all institutions.Information is available at: Open-ended working group on ageing for the purpose of strengthening the protection of the human rights of older persons: General Assembly resolution 65/182. New York: United Nations; $2011 \quad$ (http://social.un.org/ageing-working-group/ documents/Chair_summary_2nd_session_OEWG_final.pdf, accessed 4 June 2015).

${ }^{6}$ This document makes reference to specific rights, such as employment, social security, protection of the family, adequate standard of living, physical and mental health, education and culture.

7 Toronto, $17^{\text {th }}$ November 2002, sponsored by the government of Ontario (Canadá), designed by a group of experts.
} 
The 2002 Toronto Declaration on the Global Prevention of Elder Abuse calls for action so that countries activate the necessary mechanisms (health, social, legal etc.) to respond to this problem through prevention and ultimately, attention.

The Charter of Rights and Responsibilities of Older People in Need of Long Term Care and Attention (2010) ${ }^{8}$, recognizes the following: right to dignity, to physical and mental wellbeing, to liberty and security; right to decide; right of privacy; right to quality care; right to information and specialized advice and to informed consent; right to continued communication and participation in society and in cultural activities; right to freedom of expression and to freedom of thought: convictions, culture and religion; right to palliative care and to the respect and dignity in agony and at the time of death; right to lodge an appeal and subsequent responsabilities.

These rights have to be recognized and respected by society at the same time that older persons have to be aware of the existing mechanisms that are available to them so they can make these rights effective. Older persons have to be able to participate actively in the development of legislation, plans, health policies, services, etc. with the objective that their needs are met.

In spite of such an extensive body of documents, declarations and charters regarding the rights of older persons, there still is no single binding document as has been achieved for other social groups like women, children or handicapped. Doctrine and jurisprudence in the various committees have an important pending task to advance in the understanding of the rights of older persons (Huenchuan, 2009:27).

Different measures elaborated by the Council of Europe ${ }^{9}$ are related to the protection of older persons in our environment. Amognst these, the Council points firstly to Recommendation $n^{\circ}$ (98) 9 from the Committee of Ministers to Member States on Dependence (Adopted by the Committee of Ministers the 18th of September, 1998, at the $641 \mathrm{~g}$ Reunion of Delegates of Ministers) which establishes:

-The coverage of the risk of dependency is an integral part of any system of social protection;

\footnotetext{
${ }^{8}$ With the participation of EDE (European Association for Directors of Residential Homes for the Elderly/Associación Europea de Directores de Centros Residenciales para las personas mayores); ANBO (Holland); BIVA(Germany); Communede St. Josse (Belgium); FNG (Fondation Nationale de Gérontologie (France); FIPAC(Italy); 50+Hellas (Greece); MZU (Slovenia); NIACE (United Kingdom); SPF-Asociación sueca de los ciudadanos seniors (Sweden) y ZIVOT90 (Czech Republic), with the support of the european programme DAPHENE III.

${ }^{9}$ The Council of Europe has passed further legislation regarding these mandates amongst which:

-Recommendation N R (87) 22, Council of Ministers, regarding detection and attention of older persons

-Recommendation N R (90) 22, Council of Ministers regarding the protection of mental health of certain vulnerable groups

-Recommendation N R (91) 2, Council of Ministers, regarding social securtiy of workers who have no special protection (as carers, relatives or volunteers who care for older persons in their home)

-Recommendation N R (92) 6, Council of Ministers regarding a coherent policy for handicapped persons, -Recommendation N R (84) 24, Council of Ministers, regarding contribuition of social security towards preventive measures.
} 
-Public powers have to guarantee the quality of the care given;

-The adequate training of the care givers offers the necessary competence to fulfill the task effectively;

-It is necessary to strengthen the social protection of care givers;

-Appropriate help for care givers reduces the burden of their task;

Member states are recommended to:

-ensure public awareness of the problem of dependence as it is presented in this recommendation;

-direct policy measures in this field according to the principles set (below);

-ensure that their legislation takes account of the general principles and measures in this recommendation and if new legislation is introduced, adopt provisions that are in line with these

The Council adopts an outlook which takes older persons into account, as evidenced in their publications, for instance the general recomendation by the Special Relator regarding Torture; the Directing Principles for Internally Displaced; the Directives on human rights issued for pharmaceutical companies in relation to access to medicine and the basic principles and directives regarding evictions and the displacement caused by development (CEPAL, 2010). However, none of these take a step towards a Universal Declaration or Treaty, which recognizes the rights of older persons. We have to take into account that "from the international committees for the defense of human rights to the valuable work regarding constitutional jurisdiction" (Cascajo, 1998:35) enough legal work has been produced for its defense; what is lacking is its consolidation within the population.

\section{PRotection OF OLDER PERSONS IN SPAIN}

The Spanish Constitution (1978) recognizes some of the rights of the elderly:

1. Articles 14 and 15 , deal with the obligation of care that public institutions have towards older persons as well as guaranteeing their access to resources

2. Article 18: All information regarding individual older persons must be treated with confidentiality, respecting the honour, privacy and image of the elderly. Public administrations must promote a positive image of the elederly in the media, including advertisements ${ }^{10}$.

3. Article 50: The public sector will guarantee that citizens have sufficient economic resources during their old age through reasonable and regularly updated pensions. Regardless of the obligations of their family members, the government will promote their wellbeing through a system of social services

\footnotetext{
${ }^{10}$ It continues to state the "legal protection of this right will mean public Administrations will inform the Judiciary of any known actions contrary to these rights, exercising if necessary, civil or criminal actions available”, but until now no legislation has included this consideration.
} 
which will address their specific problems of health, housing, culture and leisure.

For older persons who are in situations of functional dependeny, such as people with diverse disabilities (intelectual, physical, sensory, psychiatric), of varied ages, not only dependent older persons whose situations can be worse due to clinical, pharmacological, social, economic and political elements (Munuera \& Alemán, 2016). For the benefit of these dependent persons

In view of this, various Spanish autonomous communities have passed laws which deal with the principles and recognition of the social rights inherent to people in situations of dependence ${ }^{11}$ (law 39/2006, 14 december 2006, Law on Dependence ${ }^{12}$ ), most of who find themselves in such situation due to their age.

\section{IV.1. Law 39/2006 Law on promotion of personal autonomy and attention to persons in situations of dependency (LPAD).}

The objective of this law is to regulate the basic conditions that will guarantee equality in the effective exercise of citizenship of those people who are in situations of dependence. In it, autonomy is defined as the capacity to control, face and make personal decisions on how to live and act in daily life (article 2). This definition has not translated into practical measures, which may explain why this law is known as Dependence law.

In its application, the priority of its objectives has been altered, autonomy having taken a second place. This law proposes that people in situations of dependence may "acquire a greater personal autonomy as well as exercise their citizenship rights fully". The expression refers to autonomy as an intellectual quality, an abstract ability to decide about ones' own life which deals more with self determination and the right to decide (Goñi, 2009).

Amongst the purposes of this law is the regulation of the basic conditions needed to promote personal autonomy and the attention of people in situation of dependence by creating a System for the Autonomy and Attention of Dependants (SAAD), with the collaboration and participation of the public sector. The biggest change this law introduced compared with previous legislation, was to consider the subjective right over the various benefits listed in article 1.1 (Alemán et al. 2013). In this way the subjective right was based on the principles of universality, equality and

\footnotetext{
${ }^{11}$ Intrinsic personal rights are protected by law 1/1982 5 may: protection of the right to honour and personal privacy and own image by law 15/1999 regarding the protection of personal data; also hay que añadir la garantía de confidencialidad de los datos personales regulada en la Law 15/1999, passed 13 December, guarantees the confidentiality of personal data. Furthermore more measures have been taken to update management of assets as is the European Rules of Inheritance or the reverse mortgage which also aims to facilitate management of asset as well as helping update the system of justice. The underlying principle being the empowerment of the Older Person (IMSERSO 2010).

${ }^{12}$ Gobierno de España Published in the Official State Bulletin (BOE) 15/12/2006.
} 
accessibility, developing a model of integral attention for the citizen. This law was a step forward regarding social protection by recognizing a basic set of subjective rights for all citizens.

Legistative treatment ${ }^{13}$ regarding attention of the dependent population has advanced considerably during the last years ${ }^{14}$. The object of current legislation is to define how to determine the economic capacity of beneficiaries and to set up their basic participation in the benefits provided by the system. Local administrations may always improve conditions.

In the Social Service laws passed by the different Spanish autonomous communities priority is given to the promotion of all benefits that allow dependent individuals to maintain their normal life habits. When it is not possible to provide care benefits in the normal habitat, residential attention will be provided. Each autonomous community is thus making the necessary changes so that benefits can be awarded taking into consideration the specific conditions and adapting them in terms of intensity, specialization, diversification and extension of the benefits. Therefore these laws also take into account the evaluation of the persons'needs. The criteria used are: a) degree of dependence b) areas of dependence c) stability or instability of the situation

Dependent people have a right to an individual intervention program (PIA) ${ }^{15}$ which is defined and designed with the knowledge and participation of the beneficiary or his/her legal representative. They are also entitled to the protection of their image as well as privilege, protection of personal data, participatation in activities that take place in the centre or service -where benefits are received-, to make claims and suggestions, to personal information contained in their files, to know the price of the services that will be provided and in general all the information they require as benefitiaries (De la Cámara, 2003). The aim is none other than to establish the benefits that are more suited

\footnotetext{
${ }^{13}$ Autonomic legislation has been widely developed but not in a uniform pattern, following the mínimum criteria set by the Interregional Council for the determination of the financial capacity of the benefitiary. Resolution dated 2 december 2008 (Secretary of State of Social Policy, Families and Attention to Dependency and Incapacity) which publishes the Agreement of the Territorial Council of the System for the Autonomy and Attention to Dependency), determining the financial capacity of the benefitiary and other criteria for participation in the financial benefits available in the System.

${ }^{14}$ The interest of this resolution lies not only in the critieria set forth but also in the possibility that autonomic regions have to improve the conditions or determine more favourable situactions for the benefit of the population. Thus, "article 8.2.d), law 39/2006, 14 December, states that the Territorial Council of the System for the Autonmy and Attention to Dependency must adopt the criteria for the participation of the benefitiary in the cost of services as well as for the determining the amount of financial benefits. Article 33 states that the financial capacity of the benefitiary will be taken into account to determine the possible contribution of the benefitiary towards the cost of the services and for the determination of the amount of financial benefit to be received. Finally, article 14.7 states that the financial capacity of the benefitiary will be deteremined as stated by law under the proposal of the Territorial Council of SAAD.

${ }^{15}$ It is the main document where all personal information is recorded, as well as recommendations so the person may achieve the greatest degree of self management possible in their daily life.. It has to be a dinamic and a result of interprofesional work. It is a roadmap and the older person participates in its drafting.
} 
to each individual as well as defining access to said benefits. When freedom to choose is not possible due to incapacity of the benefitiary, social services have to ensure their legal protection (Alemán et al., 2013).

On December 31 ${ }^{\text {st }}$, 2011, the System of Aid in Dependency (Sistema de Ayuda a la Dependencia) had 738.587 beneficiaries. A year later there were 751.551 benefitiaries: an increase of 12.964 people or 1.75\% in one year. By 2013 (31st December) the increase is of 15.255 beneficiaries. If we compare the figures of December 31 ${ }^{\text {st }}, 2011$ (738.587) with those of March 2017, the net increase is of 139.621 benefitiaries (totalling 878.208I people). The following graph shows the type of benefits received. Currently the most demanded benefit is the economic compensation for family care, which 367.402 benefitiaries get. An interesting fact is that few people benefit from personal assitants; it is in the Basque Country where the highest numbers are found (5.506) as results from the following table: 
M. Pilar Munuera Gómez, Ma Elena Blanco LarrieuX BENEFITIARIES AND BENEFITS RECEIVED

\begin{tabular}{|c|c|c|c|c|c|c|c|c|c|c|c|c|c|c|c|c|c|c|c|c|}
\hline \multirow[t]{2}{*}{$\begin{array}{l}\text { GEOGRAPHICAL } \\
\text { REGION }\end{array}$} & \multirow{2}{*}{\begin{tabular}{|c} 
BENEFITIA \\
RIES \\
RECEIVIN \\
G \\
BENEFITS \\
\\
\\
$\mathrm{N}^{\circ}$ \\
\end{tabular}} & \multicolumn{2}{|c|}{$\begin{array}{l}\text { PREVENTION, } \\
\text { DEPENDENCY } \\
\text { AND PERSONAL } \\
\text { CARE }\end{array}$} & \multicolumn{2}{|c|}{$\begin{array}{l}\text { REMOTE } \\
\text { ASSISTANCE }\end{array}$} & \multicolumn{2}{|c|}{ HOME CARE } & \multicolumn{2}{|c|}{\begin{tabular}{|c|} 
DAY/NIGHT \\
CARE CENTRES
\end{tabular}} & \multicolumn{2}{|c|}{ HOMES } & \multicolumn{2}{|c|}{$\begin{array}{l}\text { SERVICE RELATED } \\
\text { FINANCIAL AID }\end{array}$} & \multicolumn{2}{|c|}{$\begin{array}{l}\text { FAMILY CARE WITH } \\
\text { FINANCIAL AID }\end{array}$} & \multicolumn{2}{|c|}{\begin{tabular}{|l} 
PERSONAL \\
ASSITANT \\
WITH \\
FINANCIAL \\
AID
\end{tabular}} & \multicolumn{2}{|c|}{ TOTAL } & \multirow{2}{*}{\begin{tabular}{|c} 
RATIO \\
BETWEEN \\
BENEFIT \\
AND \\
BENEFITIA \\
RIES \\
\\
$\mathrm{N}^{\circ}$ \\
\end{tabular}} \\
\hline & & $\mathrm{N}^{\circ}$ & $\%$ & $\mathrm{~N}^{\circ}$ & $\%$ & $\mathrm{~N}^{0}$ & $\%$ & $\mathrm{~N}^{\circ}$ & $\%$ & $\mathrm{~N}^{\circ}$ & $\%$ & $\mathrm{~N}^{\circ}$ & $\%$ & $\mathrm{~N}^{\circ}$ & $\%$ & $\mathrm{~N}^{\circ}$ & $\%$ & $\mathrm{~N}^{\circ}$ & $\%$ & \\
\hline Andalucía & 184.895 & 856 & 0,36 & 76.206 & 32,15 & 50.881 & 21,46 & 13.191 & 5,56 & 23.182 & $\begin{array}{l}9,78 \\
\end{array}$ & 3.132 & 1,32 & 69.598 & 29,36 & 9 & 0,00 & \begin{tabular}{|l|}
237.055 \\
\end{tabular} & 100,00 & 1,28 \\
\hline Aragón & 22.055 & 2.121 & 8,79 & 220 & 0,91 & 1.283 & 5,32 & 1.402 & 5,81 & 3.725 & 15,44 & 4.577 & 18,98 & 10.790 & 44,74 & 0 & 0,00 & \begin{tabular}{|l|}
24.118 \\
\end{tabular} & 100,00 & 1,09 \\
\hline $\begin{array}{l}\text { Asturias } \\
\text { (Principado de) }\end{array}$ & 20.440 & 5.612 & 21,47 & 937 & 3,59 & 3.508 & 13,42 & 2.250 & 8,61 & 2.967 & 11,35 & 2.322 & 8,89 & 8.535 & 32,66 & 2 & 0,01 & \begin{tabular}{|l|}
26.133 \\
\end{tabular} & 100,00 & 1,28 \\
\hline Illes Balears & 15.319 & 185 & 1,18 & 260 & 1,66 & 434 & 2,77 & 1.030 & 6,57 & 2.220 & 14,17 & 84 & 5,00 & 10.757 & 68,65 & 0 & 0,00 & 15.670 & 100,00 & 1,02 \\
\hline Canarias & 16.439 & 32 & 0,19 & 630 & 3,72 & 23 & 0,14 & 3.551 & 20,95 & 3.365 & 19,85 & 2.438 & 14,38 & 6.911 & 40,77 & 0 & 0,00 & \begin{tabular}{|l|}
16.950 \\
\end{tabular} & 100,00 & 1,03 \\
\hline Cantabria & 14.855 & 0 & 0,00 & 1.224 & 7,41 & 962 & 5,82 & 1.699 & 10,28 & 4.266 & 25,81 & 0 & 0,00 & 8.375 & 50,68 & 0 & 0,00 & \begin{tabular}{|l|}
16.526 \\
\end{tabular} & 100,00 & 1,11 \\
\hline \begin{tabular}{|l|} 
Castilla y León \\
\end{tabular} & 85.055 & 12.500 & 11,57 & 8.320 & 7,70 & 22.274 & 20,62 & 8.276 & 7,66 & 8.286 & 7,67 & 4.315 & 22,51 & 23.744 & 21,98 & 321 & 0,30 & \begin{tabular}{|l|}
108.036 \\
\end{tabular} & 100,00 & 1,27 \\
\hline Castilla-La Mancha & 43.119 & 4.236 & 7,94 & 6.463 & 12,11 & 11.198 & 20,99 & 2.919 & 5,47 & 11.254 & 21,09 & 3.923 & 7,35 & 13.352 & 25,02 & 11 & 0,02 & \begin{tabular}{|l|}
53.356 \\
\end{tabular} & 100,00 & 1,24 \\
\hline Catalunya & 131.905 & 1.153 & 0,70 & 16.529 & 9,98 & 2.672 & 13,69 & 10.731 & 6,48 & 26.047 & 15,73 & 10.175 & 6,15 & 78.261 & 47,26 & 13 & 0,01 & \begin{tabular}{|l|}
165.581 \\
\end{tabular} & 100,00 & 1,26 \\
\hline \begin{tabular}{|l|} 
Comunitat \\
Valenciana
\end{tabular} & 52.740 & 498 & 0,88 & 4.221 & 7,46 & 0 & 0,00 & 6.439 & 11,37 & 10.317 & 18,22 & 6.278 & 11,09 & 28.855 & 50,97 & 6 & 0,01 & \begin{tabular}{|l|}
56.614 \\
\end{tabular} & 100,00 & 1,07 \\
\hline Extremadura & 24.497 & 1.056 & 3,91 & .692 & 6,27 & 729 & 2,70 & 1.741 & 6,45 & 4.398 & 16,30 & 35 & 38,68 & 0.92 & 25,68 & U & 0,00 & \begin{tabular}{|l|}
26.978 \\
\end{tabular} & 100,00 & 1,10 \\
\hline Galicia & 48.425 & 3.319 & 6,10 & 2.670 & 4,90 & 16.425 & 30,17 & 6.790 & 12,47 & 7.558 & 13,88 & 4.930 & 9,06 & 12.665 & 23,26 & 87 & 0,16 & \begin{tabular}{|l|}
54.444 \\
\end{tabular} & 100,00 & 1,12 \\
\hline $\begin{array}{l}\text { Madrid } \\
\text { (Comunidad de) }\end{array}$ & 108.734 & 2.897 & 2,03 & 33.539 & 23,45 & 31.920 & 22,32 & 15.219 & 10,64 & 22.681 & 15,86 & 12.596 & 8,81 & 24.104 & 16,85 & 69 & 0,05 & \begin{tabular}{|l|}
143.025 \\
\end{tabular} & 100,00 & 1,32 \\
\hline $\begin{array}{l}\text { Murcia ( Región } \\
\text { de) }\end{array}$ & 32.133 & 3.584 & 8,91 & 5.251 & 13,05 & 219 & 0,54 & 3.521 & 8,75 & 4.175 & 10,38 & 1.892 & 4,70 & 21.595 & 53,67 & 0 & 0,00 & 40.237 & 100,00 & 1,25 \\
\hline $\begin{array}{l}\text { Navarra } \\
\text { (Comunidad Foral } \\
\text { de) }\end{array}$ & 10.212 & 188 & 1,49 & 1.397 & \begin{tabular}{ll|}
11,07 \\
\end{tabular} & 828 & 6,56 & 276 & 2,19 & 1.839 & 14,57 & 1.076 & 8,53 & 7.014 & 55,58 & 2 & 0,02 & \begin{tabular}{|l|}
12.620 \\
\end{tabular} & 100,00 & 1,24 \\
\hline País Vasco & 57.358 & 149 & 0,21 & 6.168 & 8,63 & 6.657 & 9,31 & 6.932 & 9,69 & 12.383 & 17,32 & 1.483 & 2,07 & 32.233 & 45,07 & \begin{tabular}{|l|}
5.506 \\
\end{tabular} & 7,70 & \begin{tabular}{|l|}
71.511 \\
\end{tabular} & 100,00 & 1,25 \\
\hline La Rioja & 7.460 & 888 & 8,47 & 2.210 & 21,09 & 1.968 & 18,78 & 885 & 8,45 & 1.404 & 13,40 & 841 & 8,03 & 2.28 & 21,79 & 0 & 0,00 & \begin{tabular}{|l|}
10.479 \\
\end{tabular} & 100,00 & 1,40 \\
\hline Ceuta y Melilla & 2.567 & 423 & 12,29 & 583 & 16,94 & 765 & 22,23 & 65 & 1,89 & 199 & 5,78 & 3 & 0,09 & 1.403 & 40,77 & 0 & 0,00 & 3.441 & 100,00 & 1,34 \\
\hline TOTAL & 878.208 & \begin{tabular}{|l|l}
39.697 \\
\end{tabular} & 3,67 & 168.520 & 15,56 & 172.746 & 15,95 & 86.917 & 8,03 & 150.266 & 13,88 & 91.200 & 8,42 & 367.402 & 33,93 & \begin{tabular}{|l|}
6.026 \\
\end{tabular} & 0,56 & \begin{tabular}{|l|}
1.082 .774 \\
\end{tabular} & 100,00 & 1,23 \\
\hline
\end{tabular}

Table 1. Benefitiaries receiving benefits. IMSERSO March-2017 
Amongst the dependent population there are more elderly persons than people from other population groups; the reasons for their dependency are varied amongst which are old age, accidents, diminishing faculties, chronic illness etc.

The demographic significance of dependence can even be estimated as the relation between those who are eligible (by age) to work and those who are not. More concretely, old age dependency is calculated by dividing the number of those over 64 years of age by those who are old enough to work. This relation is changing as there are increasingly more unemployed for every employed person (...), or more unemployed than working, rising number of how many receive benefits compared to those who make their social security contributions. Problems can be predicted from the way these relationships develop (Pérez Díaz, 2010:25).

Nowadays older persons are defined as dependents, creating an image of needing help, an image related to the deterioration of the body the older person inhabits. With this simplistic imagery other dimensions of ageing are ignored (existential, psychological and social), which are the basis of the processes and relationships between individuals and amongst human groups. Thus the problem of the place older people occupy in society is hidden as is the role that social policies have to play in guaranteeing their rights as citizens, the enjoyment of their surroundings and in general a social organization which is adapted to their specific needs (García, Rabadán y Sánchez, 2006:37). From the sociological point of view, satisfactory ageing may be understood as a concept that goes beyond the definition of the person as a psychological or biological being, and places emphasis on the social collective (Bazo, 2011:23)

The concept of depence is not univocal but complex, ambivalent, and is the result of various social causes, individual, social, institutional which manifest in varied ways. Thus, the dependent person will be so not just because of individual or medical reasons but also as a result of limitations which many times are imposed by society (Asís \& Palacios, 2008: 24). Older persons should be able to bring take decisions safely within their families and a nurturing social environment (Armadans, Codina \& Pestana, 2016).

The Second World Assembly on Ageing's target is that anyone regardless of where they may be, may age with security and dignity and that older persons can continue participating in their communities making use of their complete range of rights (Leturia \& Etxaniz, 2009:17).

\section{INITIATIVES DEVELOPED IN RELATION TO THE RIGHTS OF OLDER PERSONS}

In Spain there have been different institutional and legislative initiatives. Barcelona City Council has developed the Open Document of the Rights and Liberties of Dependent Older Persons, authored by Barcelona City Council ${ }^{16}$ in collaboration with ${ }^{17}$ the Council of older persons in $2003^{18}$. This process led to the presentation of the

\footnotetext{
${ }^{16}$ Information available at: http://w110.bcn.cat/portal/site/ConsellAssessorGentGran?lang=es_ES

17 Amongst these documents was the Charter of Rights and Liberties of the dependent older person, Ministére de l' Emplor et de la Solidarité y la Fondation Nacionale de Gérontologie, France.

18 1. Right to own decision, including expressing own wishes and choice of activities, and to be recognized as full citizens throughout their old age,
} 
"Guideliness for action regarding older persons. Proposals and measures to ensure older persons can exercise their rights”, in October 2015.

In 2011 a revised text, submitted to wide spheres of participation, maintains some of the earlier rights recognized such as access, services, early attention, but also includes the idea of rights and responsibilities of older persons in maintaing their state of health and avoiding dependence. At the end, the text states that all administrations must respect these rights and adopt the necessary measures in all fields that are within the jurisdiction of the city of Barcelona. Dependence Law (law 39/2006) dated December 14, 2006 reinstates the rights of dependent citizens as subjective rights existing at state level. This law recognizes the subjective right of dependents and in article 4 states the rights and obligations of all citizens in situations of dependence.

At state level two laws stand out in the acknowledgment of the rights of older persons and their protection: Andalucía law on attention and protection of older persons, law 6/1999 (7 july, 1999), published in BOE 29/09/1999), and the law on attention and protection of older persons of Castilla y León (law 5/2003, 3rd April 2003). The law of Andalucía aims to promote the quality of life and the protection of older persons over 65 years of age; it acknowledges the rights of older persons. The law of Castilla y León includes the following rights: the right to equality, physical, moral and mental integrity; honour, privacy and personal image; freedom of thought, religion and worship; information and expression; the right of participation and association; the right to culture, leisure and sport, the right to adequate housing; legal protection and the right to financial protection which permits their personal autonomy. Other local laws protect the rights of older persons in care, amongst which is law of assistance and protection of the older person, law 7/1991, passed in Asturias, on April 5 ${ }^{\text {th }}, 1991$.

The anlaysis of these documents shows the relevance the respect of rights of older persons must have and which society needs to guarantee.

2. Right to sufficient income, as well as to management of own assets

3. Right to adequate legal protection, both of the person and of their goods, especially the mentally impaired

4. Right to early diagnose and access to adequate medical attention

5. Right to take part in decisions regarding care received and alternative places of residence

6. Right to chose the place of residence, be it in the person's home or community while possible or in a care institution

7. Right to be protected from any form of abuse or violence

8. Right to recieve adequate attention in line with the dependency in a care home where all needs (social, sensory, psychological...) are taken care of

9. Right to nearby services of the quality needed by the person.

10. Right of the dependent older person to receive care by adequately trained personnel

11. Right to actions for prevention of dependency during the lifetime

12. Right to maintain family and friend relationships of the carers of dependent older persons

13. Right of information, awareness of society as to the difficulties dependent older persons face

14. Assurance that all administrations take into account the rights that this document recognizes and take appropriate measures to make them effective

Right to a document which strengthens the exercise of the rights of the older person following the directives on active ageing and generational solidarity agreed in Brussels 2012. 


\section{LEgAL PROTECTION OF THE OLDER PERSON. PEOPLE IN CARE.}

Care homes or residential habitats where there is a certain amount of control or restriction on exits is regulated by article 763 of Law 1/2000 (7th january 2000) which states that when a person is unable to decide due to psychological reasons, whether to stay at home or internment, judicial authorization will be recquired. The judge of the jurisdiction where the person resides will be competent, not taking into account if the person is under the care of parents or tutors. The authorization will be given before admittance into care, except in cases of emergency. Previously parents used to be admitted into a closed institution based on the decision of their children or care takers. This has been changed to comply with the constitutional mandate that "no one can be deprived of their liberty except as stipulated by law” (article 17).

Another matter for discussion is the use of retainers, considering both physical restraints or chemical ones (drugs). The intention of not running undue risks with older persons who are affected by certain pathologies may lead to extreme measures which limit their liberty. These situations have to be examined closely and alternative solutions found.

A greater awareness on legal institutions related to incapacity and care of older persons and a better knowledge of what these entail would reinforce demands of better regulation on behalf of older persons which would greatly benefit all actors: legislators, judges, attorneys and older persons themselves because this would imply the effective recognition of their residual abilities without delay, avoiding the drastic connotations that declarations of incapacity entail.

There must be a clear reference regarding the role of the family in the care of older persons. Within this framework it is our task to update important features of this topic in coming years, particularly the challenge of adapting legal institutions to ensure the rights of fragile citizens, especially those affected with cognitive deficiencies who may need to be placed in care. In this sense significant changes are taking place both nationally and internationally.

A framework of integral attention of older persons requires their active participation and informed decision making regarding their health and welfare, a perspective which is also fundamental for person centered health care (OMS, 2015:16). We must guarantee the participation of older persons in society, access to the use of services as well as voluntary cease of the use of these, participation in the management of the welfare system as well as the free association of the users for the defense of their interests (Alemán et al., 2013).

\section{CONCLUSIONS}

Necessary measures have to be taken to avoid the growing ageism reflected nowadays in society, which hinders participation of older persons.

The recognition of human rights by means of national legislation could change the lives of older persons. Budgetary provisions have to be made to accompany existing legislation so that financial and professional support can make it effective. 
The rights of older persons must be guaranteed by means of a coordinated set of actions resulting from all sectors of society since these all play an important role with respect to older people.

The protection of the rights of older persons will help to prevent social discrimination so that they may be treated with dignity. They are entitled to the respect of their rights as are all other members of society.

Legislation which supports the rights of older persons will allow them to make their own decisions in those matters which are relevant to their lives. It would also allow for the punishment of negligent behaviour against them as well as the correction of existing situations of illtreatment or abuse.

The recognition of human rights can change peoples' lives. The defense of the rights of older persons will help them lead their lives safely and with dignity as most other population groups are entitled to do.

In Spain several important laws dealing with this issue have been passed. But there is still no single comprehensive law on the subject. The legal framework can be improved. As citizens, older persons enjoy the maximum legal protection under the Constitution in view of the more vulnerable situation they may find themselves in. Article 50 specifically establishes both the adequacy of pensions and the establishment of a network of social services.

Rights recognized in different social services laws passed by the various autonomic communities containing specific measures for protecting older persons' rights could be incorporated to protect also those in situations of dependence.

\section{REFERENCES}

Abreu \& Abreu, J. C. (2009). Derechos Humanos, intereses difusos y medio ambiente: un problema jurídico insoslayable. VI Congreso Iberoamericano de Academias de Derecho. Academia Mexicana de Jurisprudencia y Legislación. Disponible en: www.acj.org u.v. 24/11/2009

Alemán, C. Alonso, J.A. \& Fernández, P. (2013). Dependencia y Servicios Sociales. $2^{\text {a }}$ edición. Navarra: Aranzadi.

Armadans, I. Codina, N. \& Pestana, J.V. Empowering Senior Citizens in Leisure Settings Through Mediation: Becoming a Mediator. Educational Gerontology, 2014, vol. 41(4), pp. 1-24.

Asís, R. de \& Palacios, A. (2007). Derechos humanos y situaciones de dependencia. Instituto de Derechos Humanos “Bartolomé de las Casas”. Madrid: Dykinson.

Bárcena Calvo, C., Iglesias Guerra, J.A., Galán Andrés, M. I., \& Abella García, V. (2009). Dependencia y edadismo. Implicaciones para el cuidado. Revista enfermería CyL. Vol. 1 - No 1, pp. 46-52

Barranco Aviles, M. C. (2015). Human rights and vulnerability. Examples of sexism and ageism. The Age of Human Rights Journal, 5 (December). pp. 29-49. 
Bazo, M. T. Teorías sobre vejez; en Gómez, R. (dire.) (2011). Salud, Demografía en la población anciana. Madrid: Alianza.

Bondia García, D. (2013). La exigibilidad del derecho a la salud en situaciones de crisis sanitarias. En Bonet Pérez, J. y Saura Estapà, J. (Eds.). El Derecho Internacional de los Derechos Humanos en períodos de crisis. Estudios desde la perspectiva de su aplicabilidad. Madrid: Marcial Pons.

Butler, R. (1969). Ageism: Another Form of Bigotry. The Gerontologist, 9, pp. 243246. DOI: https://doi.org/10.1093/geront/9.4_Part_1.243

Cascajo Castro, J. L. Concepto de derechos humanos y problemas actuales. Derechos y Libertades, 1993, n 1, pp. 33-99.

Castro Cid, Benito de (1982), “El Reconocimiento de los Derechos Humanos”. Ed. Tecnos. Madrid.

CEPAL (Comisión Económica para América Latina y el Caribe) (2010). Propuesta de estrategia para avanzar, desde la perspectiva de América Latina y el Caribe, hacia una convención internacional sobre los derechos humanos de las personas de edad. CEPAL: Santiago de Chile.

De la Cámara, JJ (2003). Derechos de los usuarios de centros residenciales para mayores. Madrid, AENOR.

García Martínez, A., Rabadán, J. A. y Sánchez, A. Mª (2006). Dependencia y Vejez. Una aproximación al debate social. Madrid: Arán.

Huenchuan, S.

- (2009). Envejecimiento, derechos humanos y políticas públicas. Santiago de Chile: CEPAL

- (2013). Perspectivas globales sobre la protección de los derechos humanos de las personas mayores, 2007-2013. Santiago de Chile. CEPAL

Huenchuan, S., \& Morlachetti, A. (2006). Análisis de los instrumentos internacionales y nacionales de derechos humanos de las personas mayores. Notas de población, 81, 50-51.

Lema Añón, C. (2012). Apogeo y crisis de la ciudadanía de la salud: Historia del derecho a la salud en el siglo XX. Madrid: Dykinson.

Leturia Arrazola, F. J., Etxaniz, N., (2009). Los derechos de las personas mayores y la prevención del maltrato. Vitoria: Ararteko.

López Oliva, J. O. (2010). La Constitución de Weimar y los Derechos Sociales. La influencia en el contexto constitucional y legal colombiano a la luz de los derechos sociales asistenciales a la seguridad social en salud. Prolegómenos. Derechos y Valores, Vol. XIII (26), 233-243.

Losada Baltar, A. Edadismo: consecuencias de los estereotipos, del prejuicio y la discriminación en la atención a personas mayores. Algunas pautas para la intervención. Madrid: Portal Mayores, Informes Portal Mayores.

(http:// www.imsersomayo-res.csic.es/documentos/losada- edadismo-01.pdf).

Consultado el 11 enero 2018

Munuera Gómez, M. P. y Alemán Bracho, C. (2015). Mediación y Dependencia. Accesibilidad Universal. Madrid: Civitas. 
OMS (2015). Informe mundial sobre el envejecimiento y la salud. Ginebra (Suiza): Organización Mundial de la Salud (OMS).

Pérez Díaz, J. (2010). Perspectivas demográficas en España: efectos a largo plazo de la Crisis. Revista del Ministerio de Trabajo e Inmigración.

Riesco Vázquez, E. (2016). Género y Generación: Influencia en la Implicación Política de los Mayores en España. RASP .Research on Ageing and Social Policy.Vol. 4 No 1 January. pp. 96-133.

Soulier, J.-P. (1997). Morir con dignidad. Una cuestión médica, una cuestión ética. Madrid: Edit. Temas de hoy. Ensayo.

Villasmil, J. \& Chirinos, L. M. (2016). Reflexiones sobre Derechos Humanos, multiculturalidad y diálogo intercultural. Opción nº. 79, pp. 197-216. 


\section{APPENDIX:}

\section{Rights recognized to Older Persons in different legal documents or declarations}

\begin{tabular}{|c|c|c|c|c|c|}
\hline 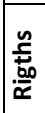 & Universal Declaration of Human Rights (1948) & Spanish Constitution (1978) & $\begin{array}{l}\text { Rights and Liberties of Dependent } \\
\text { Older Personsa (Barcelona, 2011) }\end{array}$ & $\begin{array}{l}\text { thaw 39/2006, 14/12/06 Promoting } \\
\text { Personal Autonmy and Care of } \\
\text { Dependent Persons (LAPAD). Art. } 4\end{array}$ & Rights of the Terminally III Patient \\
\hline 志 & $\begin{array}{l}\text { Art. 3. Everyone has the right to life, liberty and security } \\
\text { of person. } \\
\text { Art. 12. No one shall be subjected to arbitrary } \\
\text { interference with his privacy, family, home or } \\
\text { correspondence, nor to attacks upon his honour and } \\
\text { reputation. Everyone has the right to the protection of } \\
\text { the law against such interference or attacks. }\end{array}$ & & $\begin{array}{l}\text { 10. Right to Maintenance of } \\
\text { Family and FriendshipTies and for } \\
\text { Relatives to receive adequate } \\
\text { support }\end{array}$ & $\begin{array}{l}\text { fa) enjoy fundamental with full respect } \\
\text { of their dignity and privacy }\end{array}$ & $\begin{array}{l}\text { 1. To be treated as a human being till the } \\
\text { end of their lives } \\
6 \text {. Maintain their values and not be } \\
\text { discriminated against because their } \\
\text { opinions differ from that of their care } \\
\text { takers }\end{array}$ \\
\hline$<$ & $\begin{array}{l}\text { Art. 13. 1. Everyone has the right to freedom of } \\
\text { movement and residence within the borders of each } \\
\text { State. }\end{array}$ & $\begin{array}{l}\text { Articles14 \&15, regarding the } \\
\text { obligation public insitutions have } \\
\text { of taking care of older persons } \\
\text { and guaranteeing their access to } \\
\text { resources }\end{array}$ & & & \\
\hline$\frac{.2}{\frac{2}{\pi}}$ & $\begin{array}{l}\text { Art. 7. All are equal before the law and are entitled } \\
\text { without any discrimination to equal protection of the law. } \\
\text { All are entitled to equal protection against any } \\
\text { discrimination in violation of this Declaration and against } \\
\text { any incitement to such discrimination. }\end{array}$ & & & $\begin{array}{l}\text { k) Equality of opportunities, non } \\
\text { discrimination and universal } \\
\text { accesibility in any and all matters } \\
\text { encompassed in this law } \\
\text { I) Non discrimination base don sexual } \\
\text { orientation or identity. }\end{array}$ & \\
\hline 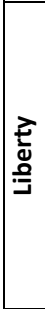 & $\begin{array}{l}\text { Art. 2. Everyone is entitled to all the rights and freedoms } \\
\text { set forth in this Declaration, without distinction of any } \\
\text { kind, such as race, colour, sex, language, religion, political } \\
\text { or other opinion, national or social origin, property, birth } \\
\text { or other status. Furthermore, no distinction shall be made } \\
\text { on the basis of the political, jurisdictional or international } \\
\text { status of the country or territory to which a person } \\
\text { belongs, whether it be independent, trust, non-self- } \\
\text { governing or under any other limitation of sovereignty. }\end{array}$ & & $\begin{array}{l}\text { 8. Right to choose the place of } \\
\text { residency, until that is possible } \\
\text { and desirable and to enjoy quality } \\
\text { services nearby when they are } \\
\text { needed. }\end{array}$ & $\begin{array}{l}\text { fh) To fully exercise their legal rights } \\
\text { ewhen residential care is not voluntary } \\
\text { y with all legal guarantees } \\
\text { e }\end{array}$ & \\
\hline
\end{tabular}




\begin{tabular}{|c|c|c|c|c|}
\hline 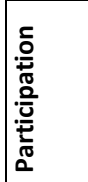 & $\begin{array}{l}\text { Art. 21. 1. Everyone has the right to take part in the } \\
\text { government of his country, directly or through freely } \\
\text { chosen representatives. } \\
\text { Art. } 21.2 \text {. Everyone has the right to equal access to public } \\
\text { service in his country. }\end{array}$ & & $\begin{array}{l}\text { e) To participate in the drawing up and } \\
\text { application of policies which affect } \\
\text { their wellbeing, be it individually or } \\
\text { through associations. }\end{array}$ & \\
\hline 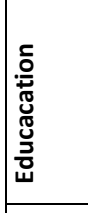 & $\begin{array}{l}\text { Art. 26. 1. Everyone has the right to education. Education } \\
\text { shall be free, at least in the elementary and fundamental } \\
\text { stages. Elementary education shall be compulsory. } \\
\text { Technical and professional education shall be made } \\
\text { generally available and higher education shall be equally } \\
\text { accessible to all on the basis of merit }\end{array}$ & & & \\
\hline 毫节 & $\begin{array}{l}\text { Art. 23. 1. Everyone has the right to work, to free choice } \\
\text { of employment, to just and favourable conditions of work } \\
\text { and toprotection against unemployment. }\end{array}$ & & & \\
\hline 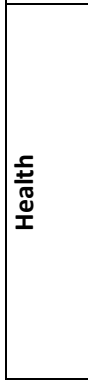 & $\begin{array}{l}\text { Art. 25. 1. Everyone has the right to a standard of living } \\
\text { adequate for the health and well-being of himself and of } \\
\text { his family, including food, clothing, housing and medical } \\
\text { care and necessary social services, and the right to } \\
\text { security in the event of unemployment, sickness, } \\
\text { disability, widowhood, old age or other lack of livelihood } \\
\text { in circumstances beyond his control. }\end{array}$ & $\begin{array}{l}\text { 6. Right to medical screening and } \\
\text { early diagnosis to receive } \\
\text { adequate health attention and the } \\
\text { promotion of autonomy. } \\
\text { 9. Right to receive attention by } \\
\text { trained professionals or family } \\
\text { members. If attention is provided } \\
\text { by health care professionals to } \\
\text { ensure the adequate number of } \\
\text { professionals is available at all } \\
\text { stages of attention. }\end{array}$ & & $\begin{array}{l}\text { 2. Receive personalized attention. } \\
\text { 4. That the appropriate means are } \\
\text { applied in order to minimize pain. } \\
\text { 8. To be treated by competent } \\
\text { professionals, who have been trained in } \\
\text { communications skills as well and that } \\
\text { they may help patients come to terms } \\
\text { with death. } \\
\text { 9. Receive the confort of friends and } \\
\text { family the patient wants throughout the } \\
\text { illness until the time of death. }\end{array}$ \\
\hline 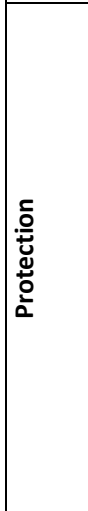 & & $\begin{array}{l}\text { Art.50. Public institutions will } 3 \text {. The right to be protected in all } \\
\text { garantee economic sufficiency of ways against any form of abuse or } \\
\text { older persons through pensions violence originating in their } \\
\text { which have to be updated placesof residence public } \\
\text { institutions or health care centers. } \\
\text { periodically. } \\
\text { They will also promote their } 5 \text {. Right to sufficient earnings as } \\
\text { wellbeing by means of a system of well as to maintain the } \\
\text { social services which will respond management and administration } \\
\text { to their specific problems in terms of their wealth and properties. } \\
\text { of health, housing, culture and } \\
\begin{array}{l}11 . \text { Right to receive all those } \\
\text { leisure. }\end{array} \\
\text { services required depending on } \\
\text { their level of dependence in a } \\
\text { health care facilty where all their } \\
\text { needs are met based in a person } \\
\text { centered approach. }\end{array}$ & & \\
\hline
\end{tabular}




\begin{tabular}{|c|c|c|c|c|c|}
\hline 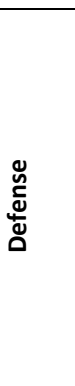 & $\begin{array}{l}\text { Art. 6. Article } 6 \\
\text { Everyone has the right to recognition everywhere as al } \\
\text { person before the law. }\end{array}$ & $\begin{array}{l}\text { Art. 18. (...).The protection of } \\
\text { older persons requires that public } \\
\text { administrations promote a } \\
\text { positive image of the older person } \\
\text { in the media and marketing } \\
\text { campaigns, avoiding any type of } \\
\text { message that harms their identity } \\
\text { and image. }\end{array}$ & $\begin{array}{l}\text { 4. Right to an adequate protection } \\
\text { before the law of the person and } \\
\text { also of theirproperty, particulary } \\
\text { in case of mentally disabled } \\
\text { gpersons. }\end{array}$ & $\begin{array}{l}\text { c) To receive adequate warning if the } \\
\text { procedures to be applied to them will } \\
\text { be used in any medical testing or part } \\
\text { of a medical investigation; written } \\
\text { authorization is a must if this is the } \\
\text { case, be it from the patient or his/her } \\
\text { legal representative. } \\
\text { j) To take appropriate legal or } \\
\text { administrative action in defense of the } \\
\text { rights recognized in paragraph } 1 \text { of this } \\
\text { article. }\end{array}$ & \\
\hline & $\begin{array}{l}\text { Art. 17. 1. Everyone has the right to own property alone as } \\
\text { well as in association with others. } \\
\text { Art. 17.2. No one shall be arbitrarily deprived of his } \\
\text { property. }\end{array}$ & & & $\begin{array}{l}\text { i) To the full exercise of their property } \\
\text { rights. }\end{array}$ & \\
\hline 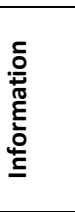 & & & $\begin{array}{l}\text { 1. Right to receive information } \\
\text { and enjoy benefits which prevent } \\
\text { dependence } \\
\text { 12. Right that society is aware and } \\
\text { sensible to the difficulties } \\
\text { dependent older persons face. }\end{array}$ & $\begin{array}{l}\text { b) To receive in understandable and } 5 \\
\text { taccesible terms complete and updatedr } \\
\text { constant information regarding theirt } \\
\text { d dependence. }\end{array}$ & $\begin{array}{l}\text { d5. To receive honest and adequate } \\
\text { dresponses to their questions, giving all } \\
\text { irthe information that the older person is } \\
\text { capable to assimilate }\end{array}$ \\
\hline 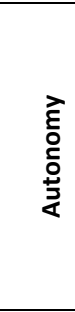 & & & $\begin{array}{l}\text { 2. Right to decide to be recognized } \\
\text { throughout old age as fully } \\
\text { capable citizens with utmost } \\
\text { respect to their dignity and } \\
\text { privacy. } \\
\text { 7. Right to take part in decision } \\
\text { making regarding their care } \\
\text { taking, support and possible } \\
\text { alternatives. }\end{array}$ & $\begin{array}{l}\text { df) To make decisions, while still in full } 3 \\
\text { ydeciding capacity, regarding } \\
\text { tarrangements over care of person andr } \\
\text { dproperty when such capacity is lost } \\
\text { g) To freely decide being admitted into } \\
\text { nresidential care. } \\
\text { e } \\
\text { e }\end{array}$ & $\begin{array}{l}\text { II3. Participate in decision making over the } \\
\text { gcare and medical treatment to be } \\
\text { dreceived }\end{array}$ \\
\hline 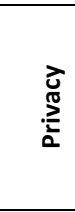 & & & & $\begin{array}{l}\text { d) That their right of privacy be } \\
\text { respected both in the acquisition of } \\
\text { their data as well as in their treatment } \\
\text { according to Law A 15/1999, 13 } \\
\text { december (Protection of Personal } \\
\text { Data) }\end{array}$ & \\
\hline
\end{tabular}




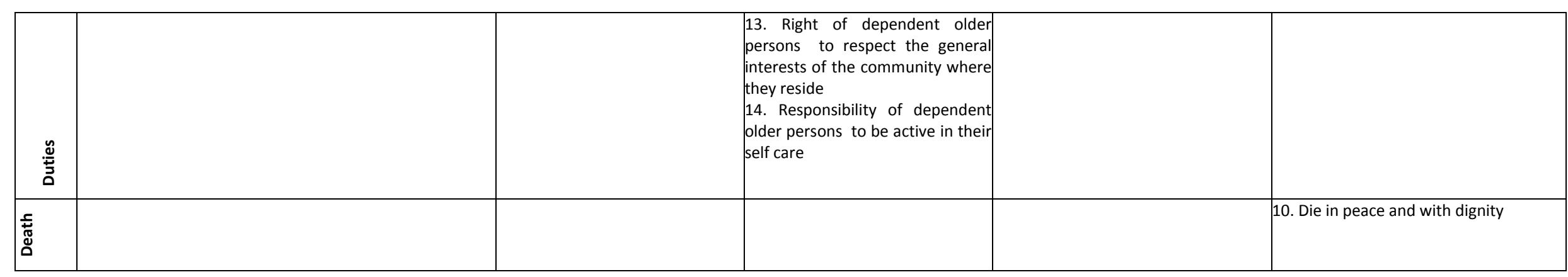

Table 2. Comparative table: rights of older persons. Elaborated by the author 